\title{
Urban Forestry in North York
}

\author{
by
}

Peter M. Morley ${ }^{1}$

\begin{abstract}
Urban forestry is defined, and the role that it plays in providing amenity and community benefits to urban life is discussed. Since 1982, the city of North York has promoted community involvement in creating natural areas in its parks and greenbelts. Three examples of this program are given.
\end{abstract}

\section{Résumé}

L'auteur définit la foresterie urbaine et le rôle qu'elle joue dans la création d'un environnement agréable et des bénéfices qu'en retire la communauté urbaine. Depuis 1982, la ville de North York a souligné son implication communautaire par la création d'espaces naturels dans ses parcs et ceintures vertes. Trois exemples illustrent ce programme.

\section{Introduction}

Canada is an urban country. At present, $85 \%$ of its population lives in cities and towns; these are predominantly within 100 miles of the US border. The movement to urbanization is increasing; it is forecast that by the year 2000 , $93 \%$ of the country's population will be urban. By contrast, the forest resource which is responsible for one out of every ten jobs in our country, is largely based in the north, usually far distant from population centres. It follows that the trees with which the bulk of the population is familiar, are those that they see growing in city streets, parks or in natural areas within the urban scene.

What has all this got to do with forestry? A great deal, according to Erik Jorgensen, former head of the Shade Tree Laboratory at the Faculty of Forestry, University of Toronto. Jorgensen (1967) was responsible for coining the term 'urban forestry', first publicly used at the Ninth Commonwealth Forestry Conference held in India in 1968. He later defined it (1974) when attending the Tenth Conference held in Britain. His definition is given in full:

"Urban forestry is a specialized branch of forestry and has as its objective the cultivation and management of trees and forests for their present and potential contributions to the physiological, sociological and economic well-being of urban society. These contributions include the over-all ameliorating effect of trees on their environment, as well as their recreational and general amenity value."

One of the main aims of forestry education, according to Jorgensen (1986), is to educate land managers not only in

Peter M. Morley Associates, 778 Avenue Road, Toronto, Ont. M5P 2 K3. timber production but in wildlife management and recreation. Urban forestry, therefore, which is 'amenity forestry' or 'community-oriented forestry' as opposed to 'economic forestry', is directly involved in managing the trees in city streets, parks and natural areas. This is in contrast to the management of forest lands, which is primarily for wood products, but also for wildlife and recreation. It also follows that while in arboriculture, the division of horticulture related to trees, major concern is the cultivation and maintenance of the individual tree as an ornament, urban forestry deals with the ecological and biological factors affecting urban trees as a group. Unmanaged forests in or adjacent to cities and towns, which Jorgensen terms 'wilderness' (I believe incorrectly), exist outside the managed urban forest, just as an unmanaged bush may exist alongside a managed economic forest.

Urban forestry at the University of Toronto was originally taught as a course to graduate students; later it became an elective option in the forestry undergraduate curriculum. Many of the graduates who took the urban forestry course, are now working as 'arborists', 'city foresters' and so on, with city or metropolitan parks and recreation departments in southern Ontario and elsewhere. Morsink (1985), the first student to graduate from this program and then employed by the Parks and Recreation Department of Windsor, Ontario, described urban forestry somewhat more succinctly: "Urban forestry is the science or profession of systematic management and cultivation of urban trees and forests, for the present and future benefits to society".

In the October 1977 issue of the 'Forestry Chronicle', various aspects of urban forestry were described by members of the Canadian Institute of Forestry's Working Group \#12, under the general heading 'Why - Urban Forestry?' Jorgensen (1977) emphasized the need for an interdisciplinary approach which would draw on the combined expertise 
of foresters, horticulturists, ecologists and social scientists. Hirvonen (1977) indicated how important a factor urban forestry was in air pollution reduction and noise abatement. Jones and MacArthur (1977) described the evolution of the Morgan Arboretum near Senneville, Quebec from a demonstration woodlot to a multiple use, people-oriented urban forest. Morsink and Burridge (1977) described the main objectives of the urban forestry program in place at Windsor, Ontario as, 'The maintenance of a permanent canopy of street and park trees, with a diversification of native tree species population'. Andresen (1977) commented on the lack of adequate legislation in Ontario to protect urban vegetation from developers and others encroaching on it, while Pollard (1977) pointed out how advanced China was in the practice of urban forestry in comparison with the West.

\section{The North York Report}

A meeting convened by the Southern Ontario Section of the Canadian Institute of Forestry dealing with urban forestry in October 1985 was my first introduction to the subject. One presentation, given by Granger (1985), arborist for North York, dealt with a decision by that city's Parks and Recreation Department to 'naturalize' certain areas in their parks for aesthetic, social and economic reasons. The concept was so interesting that a decision was made to examine this program in more detail, to look at how it got started, and record some of the achievements made to date.

A report entitled 'Naturalization Areas in North York' (1985) written by the City Parks and Recreation Department in April of that year, was approved by City Council. The report represented two years' research and field work by the Parks Services Branch under Granger's supervision and coordination. The term 'naturalization' referred to the replanting or establishment of wooded areas within the city's park system. The report stated as its objective 'The improvement and promotion of natural areas for recreation and environmental enhancement.'

Natural areas in North York, as in other urban areas, consist of remnant forests, wetland and meadow vegetation. Such areas, if left without artificial intervention like mowing, will usually regenerate naturally, provided that there is a viable seed source present. In these areas, especially on hillsides and in ravines, the need for labour intensive grooming is questioned, particularly as it is becoming increasingly expensive. It is more logical to retain such areas in their natural state and add to them from adjacent existing 'manicured' parkland to secure a wooded area as a biological entity. By doing so, not only are labour costs considerably reduced but the incremental growth of the trees already present, will greatly increase.

The report went into several reasons why natural areas make good sense for North York. The city's population is increasing (it is now over 570000 ). While this results in a growing demand for various forms of recreation, park expansion is limited. Most of the population is also growing older, so there is less demand for facilities for organized sports and a greater need for unorganized opportunities for recreation. An earlier study conducted by the Ontario Ministry of Culture and Recreation bears this out. It showed that the five most popular year-round activities in the province were walking, general exercise, jogging/running, swimming and bicycling. It stressed that the availability of facilities to perform such activities was one of the most important ways of encouraging an individual to begin, or to continue, to participate in unorganized or spontaneous activity. Finally, the report said that increasing affluence of the population and increased leisure time meant that much more importance must be placed on providing for such recreation.

Special interest groups such as the Toronto FieldNaturalists Club had long pleaded for retention of natural areas in municipalities for the unorganized enjoyment of naturalists and interested residents, as well as providing a habitat for the many species of wildlife living in urban Ontario. Besides the recreational aspect, such considerations as the aesthetic, psychological and educational advantages of natural areas, were cited. Practical considerations also required that the needs for human safety be provided for, for example, by ensuring that slopes in ravines and river banks were stabilized.

The Parks Department report, identified 20 potential naturalization areas within the city limits (see Fig. 1). These areas consisted of woodlots, naturalized areas, ravines and parks currently under turf maintenance that were possible candidates for future planting projects. Reforestation of these areas could be achieved in various ways. In an existing woodlot, where a viable source of seed was present and lawn mowing discontinued, the process of natural regeneration would take over. In time, establishment of native tree species and herbaceous growth would occur. This is the most inexpensive method, but takes a long time. In open areas, two methods are proposed, with managed succession being one alternative. Here pioneer or intermediate species are introduced, thus helping to adjust drainage, fix nitrogen and stimulate soil micro-organisms. The other alternative was planting climax species at the onset. This gives much faster results, but is the most expensive method as it requires management from the time of initial planting until full maturity. In all cases, aesthetics requires that the border or edge of such a created natural area be well defined, for both functional and visual reasons. Straight lines should be avoided, and where seating or walkways are incorporated into them, such should be properly maintained.

Public awareness and community involvement are essential for any program of urban forestry to be a success. The report suggested some of the methods by which this could be achieved. Slide presentations, promoting the ecological, recreational, and inspirational values of natural areas, should be available for showing to community organizations, groups of school children, and others. Literature, explaining and promoting the concept, is valuable in getting local residents involved. Signs, indicating where regeneration programs have been initiated and where extensive grass cutting has been eliminated, should explain the reasons for doing so and the benefits that are expected to accrue.

\section{Three North York Projects}

Community involvement requires individual or group participation and these have their focus in 'Arbor Days' usually held in the spring of the year. Joint efforts are needed between planting groups. Community volunteers or school children should work with Parks staff, the former providing the labour, while the Parks staff supply the young trees for planting, as well as shovels, buckets (for water), mulch and most important of all, supervision. Examples of three different projects in North York are described, each performed under somewhat different conditions. These involved the Driftwood Community Centre, the Finch East Greenbelt, and the Zion Historical School grounds. 


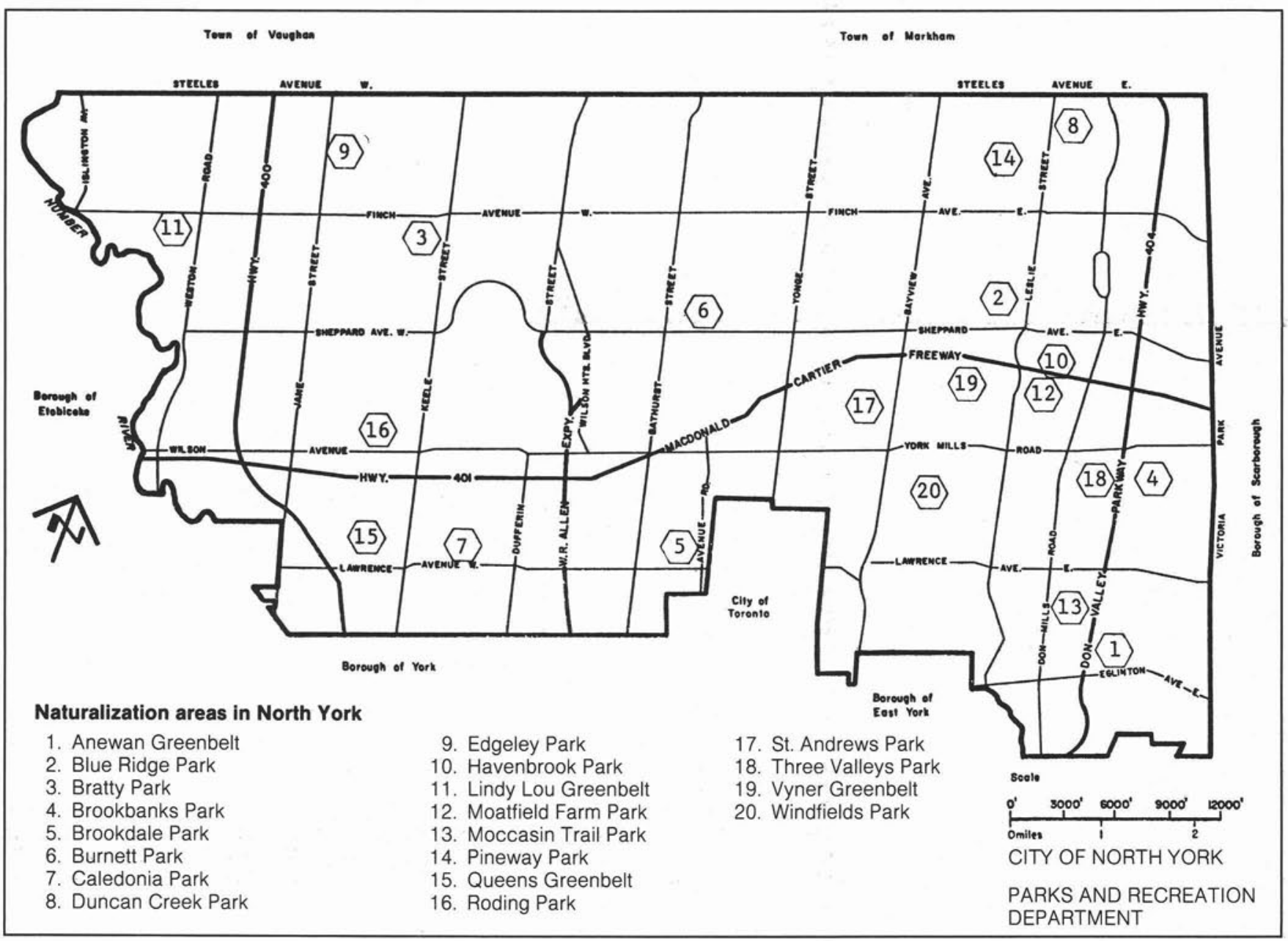

Figure 1. Naturalization Areas in North York

Driftwood Community Centre provided one of the early test plots for the natural area concept. A grove of trees south of the Centre had originally been part of a maple-beech forest. These trees began to decline in vigour following construction of the Centre, a natural consequence of the use of lawn mowers and herbicides employed to give a manicured appearance to the surroundings. Soil compaction had resulted, evidence of which was apparent at the base of the trees where the roots had become exposed; in some cases the bark had been scarred. Crown damage was also evident.

Granger (1986) described how in April 1982, two Arbor Day programs were sponsored by the Parks and Recreation Department to obtain a cost comparison. Traditional landscaping with specimen-size trees and shrub beds performed by the Parks Department personnel was costed against the non-traditional underplanting of seedlings and woodchip mulching done by school children and community volunteers. Each site was approximately one acre in size. To be really objective, the cost of comparison for both methods included the initial plant material, equipment and labour costs for planting, and maintenance costs (including mowing along pathways and annual rodent repellent application in the natural area) for a three-year period following planting. Total costs for an acre of manicured, formalized parkland, complete with shrub beds and weekly seasonal maintenance for the three years was $\$ 44028$ (1982 dollars). In contrast, an acre of reforested parkland, including three years follow-up maintenance, totalled only $\$ 4875$. Aside from these cost benefits, the environmental considerations of less noise, exhaust fumes and energy consumption in labour, equipment and fuel made the change to creating a natural area that much more attractive.

Since mowing has stopped the results have been spectacular. A good mixed understorey appeared, while the closing of the canopy, as the trees returned to vigour, meant that the tall grasses, originally present after mowing was discontinued, became shaded out. Dogwood and sumac have returned, while birds and small wild animals now occupy the woodlot. The community volunteers responsible for the initial planting gained a sense of stewardship for the park woodlot while the appearance of the Centre has greatly improved. It is now in a very pleasant setting, framed by the natural grove of trees, shrubs and grasses.

Pineway Park (see map) forms part of the Finch East greenbelt. It has been 'adopted' by students of Janice Palmer's Environmental Science class at North Toronto Collegiate. Pineway consists of a number of steepish slopes, 


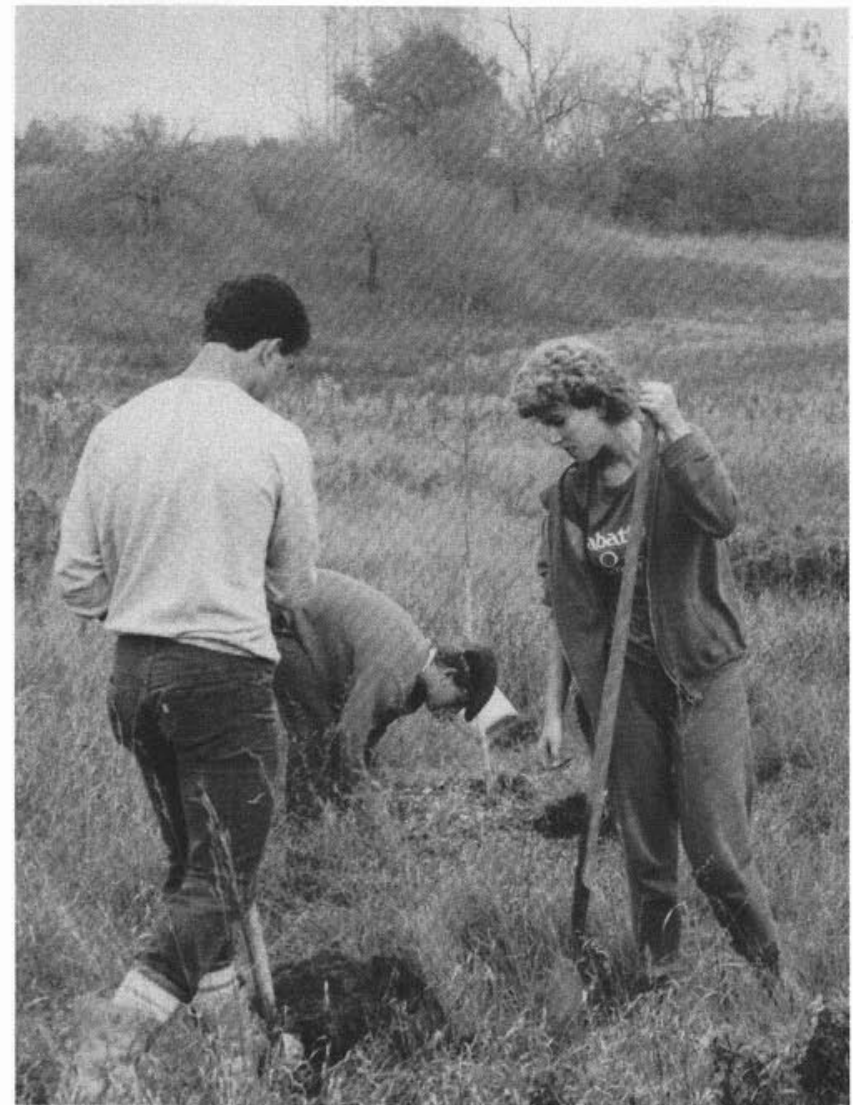

Figure 2. Pineway Park students at North Toronto Collegiate spring planting 1986.

which formed the original banks fo the East Branch of the Don River. Below the slopes are flat, rather boggy areas that are sometimes flooded at higher water in the spring. Pineway is an ideal candidate for a natural area since erosion is always a problem on the banks, particularly where there has been winter traffic of sleds or toboggans; the coarse grass and wet ground on the flats makes for difficult mowing. When visiting the area in April 1986, I learned that this was the fourth year of the project. After the students had assembled at the designated planting area, they first received a short instruction talk by Bill Granger, which emphasized the importance of first removing the coarse sod before digging the hole. The hole must be big enough to permit spreading of the roots and deep enough to ensure that the root collar is planted at ground level. Each tree planted must be at least a shovel handle length away from its neighbour. The importance of watering after planting was impressed on the students, although on this particular day with a fine drizzle of rain falling this was not so necessary. Finally, the hole must be refilled with sufficient soil, lightly tamped to remove air pockets, followed by the application of wood chip mulch around the young trees; it is especially important that this be done on the downside of slopes. Trees being planted were about 5 feet tall, five to six years old and were native species. Black walnut, mountain and white ash, were supplied from the Metro Conservation Authority's nursery at Woodbridge.

The students appeared to be doing a very conscientious job in spite of the weather and this was confirmed by Bill Granger who said that checks run on last year's work had shown close to a $90 \%$ success rate. This is remarkable as

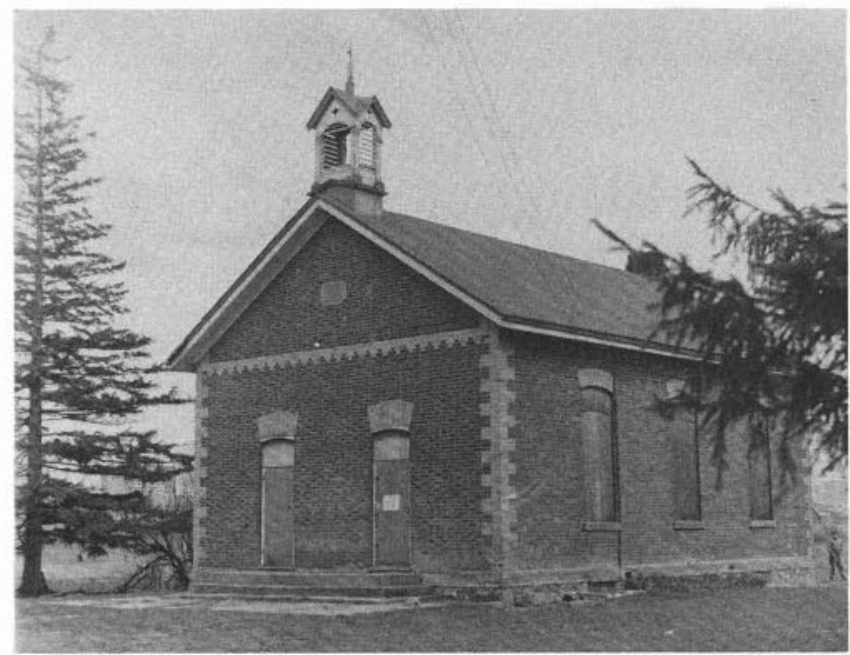

Figure 3. Zion school in 1969. Photo by North York Historical Board.

professional planters in commercial operations seldom do as well. Janice Palmer said that many former students had returned a year or two after planting, to see how 'their' trees were performing. "A day out here planting gives a student a much better appreciation of all the factors affecting our environment, than they would ever get in the classroom" she said.

A brief tour of some of the earlier plantings, showed that voles caused the biggest damage to the trees by chewing the bark, sometimes girdling the whole base and causing the death of the tree. It is now planned to use the same class to place fresh woodchips and apply rodent repellent in the fall of 1987. This treatment should discourage vermin and also prevent encroachment by other competing vegetation. Vandalism, has not yet been a problem. The residents of houses adjoining the park have taken a lively interest in the project and can be relied upon to monitor any such activity.

The planting of the grounds surrounding Zion Historical School which also took place in the spring of 1987 , represented the re-enactment of a little bit of Ontario's history. Students from area elementary schools planted two rows of white spruce around the school building. By doing so, they

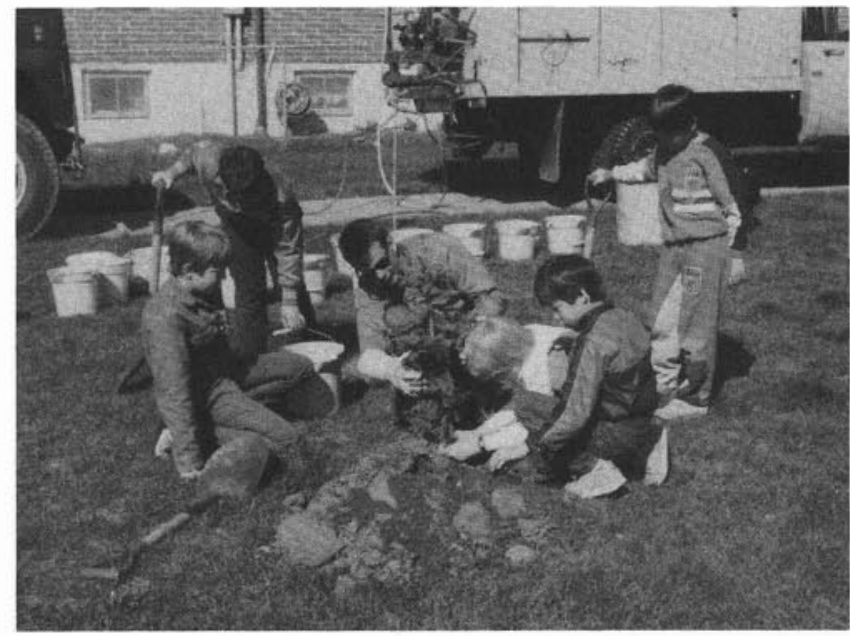

Figure 4. Finch P.S. students helping Parks employee. Zion Historical Schoolhouse 1987 
were replicating a similar planting performed 90 years ago in 1897 by a local farmer, named John Bell. Bell, almost certainly aided by the students of the school at that time, planted the spruce around the school building, probably to act as a windbreak. The schoolhouse at that time was surrounded by open farmland.

Zion School was built in 1869 to serve the small farming community of L'Amaroux. Its name was an anglicized version of the founder of the settlement, Josue L'Amoreaux, a loyalist Huguenot, who escaped after the end of the American Revolutionary War. This one room 'little red schoolhouse' served generations of area inhabitants until 1959, when it was boarded up. Credit for its reopening must go to Betty Sutherland, a North York alderman during the seventies, who agitated in Council for its restoration as an educational resource. it was re-opened in the fall of 1985.

Barbara Roblin, the first schoolmistress appointed by the new owners, the North York Historical Board, managed to obtain some sketches of the old school layout from a Mrs. Florence Coulson who had attended the school from 19111918. These showed the former position of the trees and led to a decision to replant white spruce on Arbor Day by primary school students from the area. This planting was a cooperative undertaking between Parks and Recreation and the Historical Board.

While the Zion Historical School grounds planting was not strictly a natural area planting, it did illustrate the importance of community involvement in urban forestry, particularly in the context of the history of the area and its effect on today's students. The Finch-Don Mills Road area where the school is located has a large ethnic population. Most of the children now attending the school had their roots very far distant from Canada, as it was at the end of the last century. Yet, watching the expression on the children's faces as Barbara Roblin described the life of farm children at that time, and later, listening to the questions that they asked her, it was clear that they found no difficulty in identifying with the period of history that she was re-creating.

\section{The Future}

What are the future plans for reforestation of park areas in North York? The successes to date have opened the door to eventual planting in many of the park areas, said Granger (1986); there are still many hillsides, wet bottomlands and remnant, deteriorating woodlots requiring treatment. A start has been made on preparing signs explaining the process and importance of these areas and several Boy Scout groups are willing to look after their installation. Desire-line pathways are being developed which will then be covered with wood chips. Eventually, most of North York's parks should have wooded areas. Granger believes that still later, there may be an opportunity to plan sustained-yield harvesting from some of the high quality hardwood stands that will develop.

It is ironic that just as the need and importance of urban forestry are beginning to be appreciated, that the process for educating more urban foresters, appears to have gone into reverse. John Andresen, who followed Erik Jorgensen as Professor of Urban Forestry, retired in June 1987. No replacement has been made and the course is no longer part of the undergraduate curriculum. In addition, Working Group \#12 which dealt with urban forestry, has been disbanded by the Canadian Institute of Forestry on the grounds that the work performed by it had no national impact! The Southern Ontario Section of the Institute has, however, been a little more farsighted. Arrangements have been made over the last few years for members of the group to use the Section newsletter as a means of communicating both with each other and with members of the Section.

\section{References}

Andresen, John W. 1977. Urban forestry legislation in Ontario. For. Chron. 53: 291-293.

Anon. 1985. Naturalization Areas in North York. Report by the Parks and Recreation Dept. City of North York. 29 pp.

Granger, Wm. B. 1986. Reforestation of urban parkland. Urban Forestry Working Group in Southern Ontario Section Newsletter, C.I.F., 2 pp.

Hirvonen, H.E. 1977. The role of urban forestry in regional landscape design. For. Chron. 53: 275-277.

Jones, A.R.C. \& J.D. MacArthur. 1977. Morgan Arboretum - A model urban forest. For. Chron. 53: 281-286.

Jorgensen, Erik. 1967. Urban Forestry: Some Problems and Proposals. Fac. For. Univ. Toronto. Proc. 9th Commonwealth For. Conf. New Delhi.

Jorgensen, Erik. 1974. Towards an urban forestry concept. For. Serv. Environ. Canada. Proc. 10th Commonwealth For. Conf.Oxford.

Jorgensen, Erik. 1977. Vegetation needs and concerns in urban areas. For Chron. 53: 267-270.

Jorgensen, Erik. 1986. Urban forestry in the rear view mirrow. Arbor. Jour. 10: 177-190.

Morsink, W.A.G. 1985. Managing urban forestry programmes in Ontario. Southern Ontario Section, C.I.F. Newsletter March $1985.6 \mathrm{pp}$.

Morsink, W.A.G. \& L.O.W. Burbidge. 1977. Urban forestry in Windsor, Ontario. For. Chron. 53: 287-290.

Pollard, D.F.W. 1977. Impressions of urban forestry in China. For. Chron. 53: 294-297.

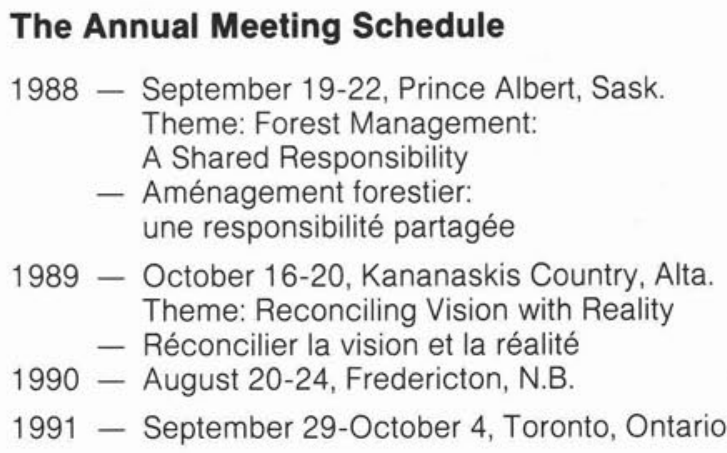

